\title{
O conceito de Estado em Immanuel Wallerstein e Hans Morgenthau: alguns apontamentos teóricos
}

\author{
Tiago Alexandre Leme Barbosa ${ }^{1}$
}

\section{RESUMO}

O presente texto busca apresentar alguns apontamentos a respeito do conceito de Estado nas Relações Internacionais. O objetivo é relacionar a abordagem de Hans Morgenthau com a concepção de Immanuel Wallerstein. Pretende-se destacar a importância do Estado nessas teorias. Para Morgenthau, o Estado defende os interesses nacionais, enquanto Wallerstein define-o como o representante da classe dominante no cenário internacional.

Palavras Chaves: Marxismo Estruturalista; Realismo; Relações Internacionais

Um dos maiores consensos das Relações Internacionais diz respeito à existência de uma Anarquia Internacional em oposição à Soberania estatal. Nogueira e Messari (2005), em uma revisão das correntes e debates da área, sinalizam para essa dualidade na disciplina. 0 ator que surge desse debate, ora central, ora menos importante, é o Estado.

A centralidade do conceito do Estado é uma das características do Realismo e das suas vertentes mais modernas. Na vertente marxista, e mesmo na teoria crítica, também é possível encontrar o debate. No caso do marxismo, percebe-se, claramente, a influência da noção de Estado como representante da burguesia ou da classe dominante.

O que se pretende, com esse texto, é apresentar, em linhas gerais, as principais características que o conceito de Estado assume nas RIs, tendo em vista que as diferentes vertentes teóricas tratam o mesmo a partir de fundamentos epistemológicos

\footnotetext{
1 Graduado em Ciências Sociais pela Universidade Federal da Grande Dourados (UFGD), mestrando em Ciência Política na Universidade Federal do Paraná. 
diferentes. Nesse texto, apresentam-se as concepções do marxismo estruturalista e do realismo.

0 ponto de partida ${ }^{2}$ é a obra de Hans Morgenthau (2003), entendida como um dos marcos iniciais da abordagem realista das RIs. O conceito de Estado trabalhado pelo autor será aqui apresentado a fim de revelar as funções e principais características dessa ferramenta analítica. Em um segundo momento, apresentaremos o tratamento que o Estado recebe na teoria marxista estruturalista de Wallerstein (2001). Não trataremos nesse texto dos chamados autores da teoria crítica ${ }^{3}$. Nem mesmo os vários críticos do realismo e as correntes neorrealistas, nem também do pensamento liberal e pósmoderno.

Morgenthau (2003) e Carr (2001) são reconhecidos como clássicos da Escola Realista de R.I. Embora fosse interessante analisar o pensamento de Carr (2001), limitamo-nos aqui ao pensamento de Morgenthau (2003). Como se sabe, uma das características do realismo é a centralidade que o conceito de Estado ocupa nas suas abordagens. Observando a obra de Morgenthau (2003), a definição de Estado que se encontra é muito semelhante à ideia weberiana.

A famosa definição de Estado em Weber (2003) remete ao monopólio legítimo da força em um determinado território, elemento que a instituição possui. A influência do conceito weberiano em Morgenthau (2003) é também percebida por Berringer4 (2001), ao comparar o conceito de Estado do realista com outro marxista clássico, Poulantzas (1986).

A herança weberiana em Morgenthau (2003) faz com que o Estado apareça em sua obra como um bloco monolítico, que atua no plano internacional buscando: aumentar, manter ou conservar o poder. Em tese, essa atitude do Estado, representado por diplomatas e militares, é consequência da anarquia internacional, que, como se sabe,

\footnotetext{
${ }^{2} 0$ presente texto faz parte dos resultados preliminares de uma pesquisa em desenvolvimento pelo autor. Na pesquisa, o objetivo é analisar o tratamento que o Estado recebeu nas RIs, desde a citada obra de Morgenthau (2003), percorrendo a obra de Liberais, neorrealistas, neo-liberais, construtivistas, etc.

3 Uma contribuição sobre a teoria crítica de Cox pode ser encontrada em Silva (2005)

${ }^{4}$ Berringer (2001) ao comparar o pensamento de Morgenthau (2003) com o de Poulantzas (1986) chega a conclusão que o marxista entende o Estado como representante da classe dominante. Mesmo que Poulantzas (1986) argumente em prol da "autonomia relativa do Estado", a instituição serve em última instância para a reprodução do capitalismo. Já o realista não percebe as "relações de classe" que acontecem na política doméstica. Ele entende a atuação do Estado enquanto representante dos interesses nacionais.
}

Conjuntura Global, Curitiba, Vol. 2, n.1, jan./mar., 2013, p. 29-33. 
é marcada pela inexistência de uma autoridade acima dos Estados. Cabe lembrar ainda no pensamento do autor as influências do conceito de natureza humana de Hobbes (1983) e Maquiavel (2001), que aparece como sendo a natureza egoísta dos Estados, a qual os motiva a buscarem apenas os seus interesses, semelhante à natureza dos seres humanos.

Já a concepção marxista de Wallerstein (2001) busca ressaltar as funções que o Estado desempenha. Nesse sentido, é muito nítida a influência da concepção de Estado de Marx e Engels (2000). Para esses autores, esta instituição tem como função manter a ordem na "sociedade burguesa". Essa posição é expressa no clássico de Engels (1982), ou mesmo em Marx e Engels (2000), onde a organização aparece como o "comitê executivo da burguesia”. Cabe ressaltar que o Estado está localizado na superestrutura, sendo o mesmo erigido sobre a infraestrutura ou a base material da sociedade capitalista 5 .

Seguindo as considerações de Wallerstein (2001), o autor aponta três características do Estado, a saber: a) Jurisdição sob um determinado território, b) capacidade de regular as relações sociais de produção no seu território, c) poder de taxar impostos. Pelas citadas três funções que os Estados têm em comum, o marxista conclui, assim, que o Estado corresponde a "alavancas políticas mais efetivas" no atual capitalismo histórico.

Partindo, então, da concepção marxista de Estado, Wallerstein (2001) especifica as funções que a instituição desempenha e que servem aos interesses do capital e desenvolvimento do "capitalismo histórico". Dentre essas funções, está, por exemplo, o recolhimento de imposto e a distribuição desigual de recursos. 0 marxista entende que à medida que o Estado recolhe impostos e investe em capitalistas, ele acaba por manter a acumulação de capital.

Em Wallerstein (2001), diferentemente de Morgenthau (2003), as relações internacionais se dão no chamado Sistema-mundo, onde os Estados operam no "sistema interestatal", formado por um conjunto de "regras formais que governam jurisdições e contratos (direito internacional) e nos limites que definem como e sob que

\footnotetext{
${ }^{5}$ A distinção entre infra-estrutura, superestrutura aparece no conhecido prefácio de Para a Crítica da Economia Política, Marx (1978).

Conjuntura Global, Curitiba, Vol. 2, n.1, jan./mar., 2013, p. 29-33. 
circunstâncias as guerras podem ser conduzidas" (Wallerstein, 2001, p. 50). Todos esses elementos contribuem para limitação da soberania estatal para o marxista.

Comparando as duas concepções acerca do papel do Estado, ficam evidentes algumas diferenças. A primeira, a ideia de que a Instituição serve para propiciar a manutenção do capitalismo, no caso de Wallerstein (2001), e em outro ponto Morgenthau (2003) argumenta que ela serve aos interesses nacionais.

Além disso, cabe lembrar que as duas concepções teóricas assentam-se em pressupostos rivais na teoria política. Enquanto o realista é tributário da concepção weberiana, o marxista é, evidentemente, informado pela concepção marxiana.

\section{Referências Bibliográficas}

BERRINGER, Tatiana. Estado e relações internacionais: uma comparação crítica entre Hans Morgenthau e NicosPoulantzas. Campinas-São Paulo. Dissertação (Mestrado). Instituto de Filosofia e Ciências Humanas. Programa de Pós-Graduação em Ciência Política. UNICAMP, 2011.

CARR, Edward Hallett. Vinte anos de crise: 1919-1939. Uma introdução ao estudo das Relações Internacionais. 2. ed. Brasília: Editora Universidade de Brasília, 2001.

ENGELS, Friedrich. A origem da família, da propriedade privada e do Estado. 8. ${ }^{a}$ ed. Rio de Janeiro: Civilização Brasileira, 1982.

HOBBES, Thomas.1983. Leviatã ou matéria, forma e poder de um Estado eclesiástico e civil. $3^{a}$ ed. São Paulo : Abril Cultural.

MAQUIAVEL, Nicolau. O Príncipe. Trad.: Maria Júlia Goldwasser. São Paulo: Martins Fontes, 2001.

MARX, Karl. Para a crítica da economia política. Os pensadores. 2.ed. São Paulo: Abril Cultural, 1978

MARX, Karl; ENGELS, Friedrich. Manifesto do partido comunista. Trad. Marco Aurélio Nogueira, Leandro Konder. 10ª edição. Editora Vozes. Petrópolis, 2000. 
MORGENTHAU, Hans J. A política entre as nações - a luta pela poder e pela paz. Brasília: Editora Universidade de Brasília: Imprensa Oficial do Estado de São Paulo: Instituto de Pesquisa de Relações Internacionais, 2003.

NOGUEIRA, João Pontes; MESSARI, Nizar. Teoria das relações internacionais: correntes e debates. Rio de Janeiro: Elsevier, 2005.

POULANTZAS, Nicos. Poder político e classes sociais. Martins Fontes, São Paulo,1986;

SILVA, Marco Antonio de Meneses. Teoria crítica em relações internacionais. Contexto int. [online]. 2005, vol.27, n.2, pp. 249-282. ISSN 0102-8529.

Wallerstein,Immanuel .Capitalismo histórico e civilização capitalista, Rio de Janeiro: Editora Contraponto, 2001, 144 p.

WEBER, Max. A política como vocação. Tradução de Maurício Tragtenberg. Brasília: Editora Universidade de Brasília, 2003. 